\title{
PENGARUH ROTASI DAN KOMPETENSI TERHADAP MOTIVASI KARYAWAN NON DOSEN SEKOLAH TEKNIK ELEKTRO DAN INFORMATIKA INSTITUT TEKNOLOGI BANDUNG
}

\author{
Rahman Faisal \\ Universitas Pamulang \\ Dosen01429@unpam.ac.id
}

\begin{abstract}
This research aimed to obtain empirical evidence about the influence of rotation and competency to motivation non Lecturer in the School of Electrical Engineering and Informatics Bandung Institute of Technology. The research results are expected to contribute in the development of management, especially human resource management. The research was conducted at the School of Electrical Engineering and Informatics Bandung Institute of Technology in Bandung, West Java. All the employees are sampled in this research. This research approach is quantitative, whereas the type of research in the form descriptive explanatory and verificative and also uses questioner as premier data to get the describing in conditions. The analysis tool in this research used path analysis. The test results of this research show and found a positive and significant effect between rotation and competency to motivation either partially or simultaneously. The implications of these findings is the realization of one attempt and have a good rotation appropriate to competency so as to improve employee motivation.
\end{abstract}

Keywords : Rotation, Competency and Motivation

\section{PENDAHULUAN}

Penjelasan UU Ketenagakerjaan No. 13 tahun 2003 yang menyebutkan bahwa pembangunan ketenagakerjaan mempunyai banyak dimensi dan keterkaitan. Hal tersebut tidak hanya dengan kepentingan tenaga kerja selama, sebelum dan sesudah masa kerja tetapi juga keterkaitan dengan kepentingan pengusaha, pemerintah, dan masyarakat. Untuk itu, diperlukan pengaturan yang menyeluruh dan komprehensif, antara lain mencakup; pengembangan sumber daya manusia, peningkatan produktivitas dan daya saing tenaga kerja, upaya perluasan kesempatan kerja, pelayanan penempatan tenaga kerja, dan pembinaan hubungan industrial. Selain itu sumber daya manusia yang berkualitas diharapkan dapat bersaing dari 
segala aspek tuntutan dunia kerja. Salah satu keberhasilan organisasi/intitusi terhadap karyawannya dapat dilihat dari motivasi mereka dalam bekerja.

Tabel 1.1

Hasil Penelitian Awal Mengenai Motivasi Karyawan

Non Dosen STEI ITB Tahun 2014

\begin{tabular}{|l|c|c|c|c|c|c|}
\hline \multirow{2}{*}{\multicolumn{1}{|c|}{ Item Pra Survey }} & \multicolumn{2}{c|}{ Frekuensi } & \multicolumn{2}{c|}{ Rata-rata } & \multicolumn{2}{c|}{ Prosentase (\%) } \\
\cline { 2 - 7 } & Ya & Tidak & Ya & Tidak & Ya & Tidak \\
\hline Kolaborasi dengan rekan kerja & 27 & 1 & 0,96 & 0,04 & 96,4 & 3,6 \\
\hline Pendapatan & 18 & 10 & 0,64 & 0,36 & 64,3 & 35,7 \\
\hline Pekerjaan Sesuai Kemampuan & 27 & 1 & 0,96 & 0,04 & 96,4 & 3,6 \\
\hline Promosi & 18 & 10 & 0,64 & 0,36 & 64,3 & 35,7 \\
\hline Kenyamanan Bekerja & 24 & 4 & 0,86 & 0,14 & 85,7 & 14,3 \\
\hline
\end{tabular}

Sumber: Data didapat dari hasil penelitian awal

Penulis melibatkan 28 responden yang dilakukan dan dikaji, dapat diasumsikan bahwa kepuasan karyawan dilapangan yang penulis lakukan, ada indikasi dari rekan kerja yang merasa bahwa gaji yang diterima belum dapat memenuhi kebutuhan yang mereka alami. Hal tersebut dapat dilihat dari presentasenya sebesar 35,7\% yang masih kurang puas dengan gaji yang mereka terima. Hasil pra survey/ observasi juga didapati bahwa pegawai merasa kurang puas dengan promosi yang ada sebesar 35,7\%. Mereka tidak merasakan efek dari promosi karena ketiadaan jenjang karir, tidak seperti ekspektasi selama bekerja. Dari observasi di lapangan, penulisi melihat adanya kompetensi beberapa karyawan di STEI ITB, yang tidak sesuai dengan bidang pekerjaannya.

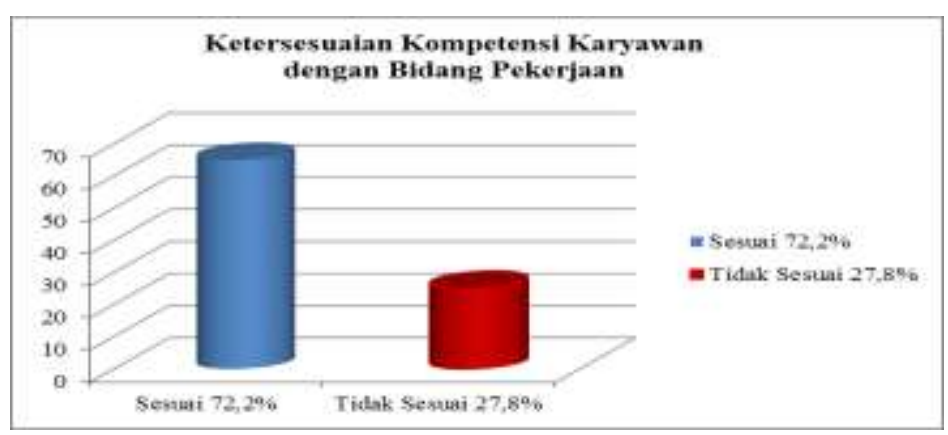

Sumber : STEI ITB 2014

Gambar 1.1

Ketersesuaian Kompetensi dengan Bidang Pekerjaan Karyawan STEI ITB 2014 
Dari tabel tersebut, dapat dilihat adanya ketidaksesuaian kompetensi karyawan dengan bidang pekerjaannya. Dari 90 karyawan, sebanyak 27,8\% karyawan tidak sesuai dari pekerjaan yang dilakukan dengan melihat latar belakang pendidikannya. Jika melihat tabel tersebut, adanya ketidaksesuaian standar dimana kompetensi merupakan hal yang diharapkan dimiliki oleh setiap orang khususnya di dunia kerja sehingga mampu berkontribusi terhadap organisasi dan atau institusi yang membawahi mereka sesuai dengan kompetensinya. Seperti diketahui bahwa kompetensi yang dimiliki individu jika dimaksimalkan peran dan fungsinya akan memiliki dampak yang baik terhadap organisasi tersebut. Setiap individu pastinya memiliki kompetensi yang berbeda satu sama lain walaupun berlatar pendidikan mungkin sama, namun belum tentu keahlian mereka sama juga satu sama lainnya. Kompetensi pengembangan profesi dari setiap individu karyawan yang ditangani dengan baik secara tidak langsung dapat memberikan efek positif guna mendorong organisasi ke arah yang lebih baik.

Hal inilah yang seyogyanya menjadikan dasar dan pertimbangan pada saat akan melakukan rotasi karyawan. Sehingga perubahan atau pertukaran karyawan tersebut sesuai dengan bidang dan kemampuan yang dimiliki. Selain itu pada hal lain mereka sudah sesuai dengan kemampuan dan minat dalam pekerjaan tersebut namun karena adanya sistem rotasi tersebut membuat karyawan tersebut menjadi bekerja dari awal atau mempelajari hal yang baru lagi. Tentunya jika hal ini terjadi akan membuat kesimbangan roda institusi akan terganggu. Hasil penelitian yang dilakukan Liu Yinhua, yang menyatakan bahwa "Job rotation produces positive learning and increases the accumulation of human capital." Jika dilakukan dengan tepat dan memenuhi hal yang dapat mendorong kearah yang lebih baik. Selain itu juga diperkuat dari hasil penelitian yang dilakukan Tolkah, (2009) yang menyatakan bahwa rotasi pekerjaan berpengaruh positif dan signifikan terhadap motivasi. Hal ini diharapkan dapat menjadikan dasar jika proses rotasi tepat dilakukan dapat meningkatkan motivasi dan ini berdampak positif pastinya untuk institusi/organsasi itu sendiri.

Berangkat dan melihat dari fenomena tersebut, penulis berasumsi bahwa motivasi karyawan diindikasikan oleh berkesesuaian terhadap kompetensi karyawan 
yang dimiliki dan juga dapat melakukan perputaran (rotasi) karyawan yang sesuai dengan peruntukannya. Berlandaskan hal tersebut, penulis melakukan penelitian lebih dalam mengenai "Pengaruh Rotasi dan Kompetensi Terhadap Motivasi Karyawan Non Dosen Sekolah Teknik Elektro dan Informatika Institut Teknologi Bandung."

\section{TELAAH LITERATUR DAN PENGEMBANGAN HIPOTESIS}

\section{Ilmu Manajemen}

Sebagaimana yang dikemukakan Nickels, McHugh dan McHugh manajeman adalah "The proces used to accomplish organizational goals through planning, organizing, directing and controlling people and other organizational resourse," (Tisnawati dan Saefullah 2010 : 6). Dari definisi diatas dapat disimpulkan bahwa manajemen dipastikan mempunyai tujuan yang ingin dicapai dalam harapannya. Selain itu manajemen juga merupakan sebuah perpaduan baik seni maupun suatu ilmu. Manajemen juga merupakan suatu proses yang terstruktur dan sistematis dan terkoordinir serta terjalin kerjasama yang terintegritas dalam pemanfaatannya.

\section{Manajemen Sumber Daya Manusia}

Kebutuhan manajemen Sumber Daya Manusia merupakan suatau hal yang kuat dan sebuah profesional tidak bisa dihindar (Arwildayanto, 2013 : 8). Hal ini merupakan keluwesan, keleluasaan sistem kerja, budaya kerja dan struktur organisasi perguruan tinggi diharapkan untuk memberikan kepuasan kepada user dalam hal ini masyarakat, baik masyarakat intelektual maupun masyarakan peminat pendidikan tinggi. Adapun fungsi manajemen sumber daya manusia salah satunya di perguruan tinggi yaitu mengacu pada proses manajemen seperti "planning, recuitment, selection, induction, apprasial, conpetation, continuty, security, bargaining dan information," Castetter, (1981 : 51) dalam Arwildayanto, (2013 : 9). 


\section{Rotasi}

Rotasi pekerjaan yang dilakukan diharapkan meliputi proses pelatihan silang dari karyawan itu sendiri, dimana dalam proses perpindahan dari satu pekerjaan ke pekerjaan lain mampu memberikan hal yang positif baik untuk karyawan itu sendiri maupun institusi/organisasi. Pada saat karyawan dirotasi, diharapkan pula karyawan dapat mempelajari pekerjaan tersebut didalam ruang lingkup institusi/organisasi yang sama baik keterampilan maupun pemahaman guna meningkatkan produktivitas institusi/organisasi yang menjadi tempat menaungi mereka. Seperti yang dikemukakan dalam Kaymaz (2010) yang menyatakan:

"Rotation can be defined as working at different tasks or in different positions for set periods of time (Jorgensen et al, 2005, p. 1723) in a planned way using lateral transfers aiming to allow employees to gain a range of knowledge, skills and competencies and is also seen as an on-the-job training technique (Gomez and Lorente, 2004, p. 241; Karadimas and Papastamatiou, 2000, p. 39), and as such is known to have an effect on employee motivation (Huang, 1999, p. 75)."

\section{Kompetensi}

Seperti yang termaktub dalam UU Ketenagakerjaan No 13 Tahun 2003 tentang ketenagakerjaan pada Bab 1 Ketentuan Umum pasal 1 butir kesepuluh, kompetensi kerja adalah kemampuan kerja setiap individu yang mencakup aspek pengetahuan, keterampilan, dan sikap kerja yang sesuai dengan standar yang ditetapkan. Kompetensi berdasarkan Peraturan Pemerintah Nomor 100 Tahun 2000, adalah kemampuan dan karakteristik yang dimiliki oleh seorang berupa pengetahuan, keterampilan dan atau sikap perilaku yang diperlukan dalam pelaksanaan tugas jabatannya.

Palan (2007), menguraikan istilah kunci dalam mendefinisikan kompetensi sebagai berikut:

1. Karakter dasar (undelying character) dapat dikatan sebagai kepribadian seseorang yang cukup dalam dan berlangsung lama. Pada definisi ini, beliau (Palan) lebih menekankan pada karakter dasar yang mengarah pada motif, karakteristik pribadi, konsep diri dan nilai-nilai seseorang. 
2. Kriteria referensi (criterion-referenced) berarti bahwa kompetensi dapat diukur berdasarkan kriteria atau standar tertentu.

3. Hubungan kausal (causality relatinship) mengindikasikan bahwa keberadaan suatu kompetensi dan pendemontrasiannya memprediksi. Kompetensi seperti motif, sifat, dan konsep diri dalam memprediksi keterampilan dan tindakan.

\section{Motivasi}

Berbicara mengenai motivasi, seperti yang diungkapkan oleh (Pramudyo, 2010), beliau mengemukakan bahwa motivasi adalah suatu kondisi yang menggerakkan seseorang ke arah suatu tujuan tertentu yang berkaitan dengan tugasnya. Lain hal seperti yang diungkapkan oleh Robbins (2008 : 222), motivasi merupakan kesediaan untuk mengeluarkan tingkat upaya yang tinggi kearah tujuan organisasi, yang dikondisikan oleh kemampuan upaya itu untuk memenuhi sesuatu kebutuhan individual.

\section{Teori Motivasi}

1. Menurut Maslow dalam Robbins, (2008 : 224) beliau mengungkapkan ada lima kebutuhan dari teori kebutuhan yang diungkapkan yaitu meliputi:

a. Physiological Needs, Fisologis yaitu meliputi rasa lapar, haus, berlindung, seksual dan kebutuhan fisik lainnya.

b. Safety dan Security Needs, Rasa aman yaitu meliputi rasa ingin dilindungi dari bahaya fisik dan emosional.

c. Affiliation atau Acceptance needs, yaitu kebutuhan sosial yang meliputi rasa kasih sayang, kepemilikan, penerimaan dan persahabatan.

\section{Teori Motivasi Menurut Frederick Herzberg}

Teori ini juga dikenal sebagai teori dua faktor atau disebut juga teori motivasi higiene. Beliau mengungkapkan bahwa hubungan seorang individu dengan pekerjaan adalah mendasar dan bahwa sikap seseorang terhadap pekerjaan bisa dengan sangat baik menentukan keberhasilan atau kegagalan. Herzberg mengungkapkan mengenai faktor interistik seperti : kemajuan, pengakuan, tanggung 
jawab dan pencapaian, (Robbins, 2008 : 227). Selain faktor motivator, Herzgerb mengungkapkan mengenai faktor kesehatan, dimana menurut Hergarb faktor kesehatan (maintenance factors) yang dimaksud yaitu mencangkup; gaji, kondisi kerja, kepastian pekerjaan, supervisi yang menyenangkan, mobil dinas dan berbagai tunjangan lainnya yang mereka terima, (Hasibuan, $2010: 110$ ).

\section{Pengembangan Hipotesis}

Hipotesis merupakan jawaban sementara terhadap rumusan masalah penelitian, dimana rumusan masalah penelitian telah dinyatakan dalam bentuk kalimat pertanyaan (Sugiyono, 2011:64).

Hal tersebut dapat dikatakan sebagai jawaban sementara, dimana jawaban yang ada dalam penelitian ini baru didasarkan pada teori yang memiliki kesamaan dan belum dapat didasarkan oleh bukti dan fakta empiris yang diperoleh dari hasil pengumpulan data.

Berdasarkan kajian dan telaah literatur di atas, maka dapat dikembangkan hipotesis sebagai berikut :

Ha1: Terdapat pengaruh rotasi terhadap motivasi karyawan Non Dosen STEI ITB baik secara parsial maupun simultan

Ha2: Terdapat pengaruh kompetensi terhadap motivasi karyawan Non Dosen STEI ITB baik secara parsial maupun simultan

\section{METODE PENELITIAN DAN PEMBAHASAN}

Penelitian ini yaitu penelitian kuantitatif, adapun alasan menggunakan tipe penelitian tersebut dikarenakan dalam keberlangsungan penelitian penulis menggunakan kuesioner dalam mengumpulkan data serta wawancara guna mendukung penelitian ini hal ini dikarenakan data yang dikumpulkan merupakan data yang berupa angka. Menurut Sugiyono (2006), metode penelitian kuantitatif dapat diartikan sebagai metode penelitian yang berlandaskan pada filsafat positivisme, digunakan untuk meneliti pada populasi atau sampel tertentu. Jenis penelitian ini bersifat explanatory research, sedangkan pendekatan penelitian ini yaitu pendekatan deskriptif dan verifikatif. Unit Obsevasi dalam penelitian ini yaitu 
para karyawan Non Dosen STEI ITB yang terdiri dari PNS (Pegawai Negeri Sipil), BHMN (Badan Hukum Milik Negara) dan Karyawan kontrak. Sedangkan lokasi penelitian dilakukan di lingkungan pendidikan yaitu di Sekolah Teknik Elektro dan Informatika Institut Teknologi Bandung Gedung Ahmad Bakrie Lantai 2, Jalan Ganesa No. 10 Bandung.

\section{Prosedur Penelitian dan Pengumpulan Data}

Pada teknik pengumpulan data dalam penelitian ini mencangkup studi lapangan dan studi kepustakaan serta proses pengujian baik validitas maupun reliabilitas. Dalam melakukan penelitian ini, penulis menggunakan Kuesioner, Observasi dan Wawancara guna mendukung penelitian yang dilakukan. Guna mendukung penelitian ini, penulis menggunakan data Primer, yaitu merupakan data yang didapatkan dan dikumpulkan dari lapangan langsung yaitu di lingkungan STEI ITB. Data primer umumnya berupa kuesioner/anget, wawancara dan lainnya. Sementara data kedua yaitu data Sekunder, merupakan data yang dikumpulkan dan diperoleh baik secara langsung maupun tidak langsung baik berupa dokumen seperti jurnal, buku, artikel, tesis maupun laporan yang berhubungan dengan penelitian yang penulis lakukan.

\section{Studi Lapangan}

Proses studi lapangan yang dimaksudnya yaitu penulis melakukan proses mulai dari pengamatan di lapangan dan lain sebagainya. Proses ini untuk memberikan gambaran mengenai klausal objek yang diteliti. Penulis juga menggunakan kuesioner/angket dalam melakukan studi di lapangan serta pelaksanaan wawancara kepada berbagai pihak yang dapat membantu penelitian ini.

\section{Kuesioner}

Dalam penelitian ini khususnya dalam prosedur pengumpulan data berupa kuesioner dan wawancara untuk dapat data yang akurat. Menurut Sugiyono (2006) kuesioner adalah teknik pengumpulan data yang dilakukan dengan cara memberi seperangkat pertanyaan atau pernyataan tertulis kepada responden untuk dijawabnya. Kuesioner dapat diberikan secara pribadi, disuratkan kepada responden, atau disebarkan secara elektronik. Untuk mengumpulkan data dari 
kuesioner ini, penulis mengembangkan kuesioner tersebut kedalam beberapa item berupa pernyataan sebanyak 18 item pernyataan dengan perinciannya yaitu:

a. Rotasi $\left(\mathrm{X}_{1}\right)$ pekerjaan sebanyak tiga penyataaan mencangkup yaitu: tembahan kemampuan, tambahan pengetahuan dan mengatasi tingkat kejenuhan kerja.

b. Kompetensi $\left(\mathrm{X}_{2}\right)$ sebanyak lima penyataan mencangkup yaitu: pengetahuan, keterampilan, konsep diri/nilai-nilai, karakteristik pribadi dan motif.

c. Motivasi (Y) sebanyak enam pernyataan meliputi pernyataan berupa prestasi, pengakuan, pekerjaan itu sendiri, tanggung jawab, kemajuan dan kemungkinan untuk berkembang.

\section{Obeservasi}

Penulis menggunakan observasi untuk dapat memperoleh informasi tentang kejadian atau reaksi yang timbul dilapangan baik untuk menangkap fenomena subjek penelitian dan untuk dapat mengetahui keadaan yang dirasakan. Selain itu observasi dilakukan untuk memperoleh gambaran yang lebih jelas tentang subjek penelitian dan tempat penelitian yang sebenarnya. Secara garis besar observasi dapat dilakukan dengan dua cara yaitu pertama dengan partisipasi, pengamat menjadi sebagai partisipan dan kedua tanpa partisipasi yaitu dimana pengamat menjadi sebagai non-partisipan (Nasution, 2008:106).

\section{Studi Keperpustakaan}

Untuk mendukung penelitian ini, penulis juga melakukan studi keperpustakaan baik melalui sumber bacaan dan atau informasi yang berkaitan dengan materi penelitian ini. Studi keperpustakaan yang penulis lakukan meliputi studi diberbagai buku yang merujuk pada penelitian, peraturan pemerintah dan sumber lainnya yang dapat mendukung pelaksanaan penyusunan penelitian ini. Proses atau alur dalam pelaksanaan penelitian yaitu dimana penulis akan melakukan observasi dilapangan dan kemudian menyebarkan angket berupa kuesioner kepada para karyawan. 


\section{Pengujian Validitas dan Reliabilitas}

\section{Uji Validitas}

Pada proses pengujian validitas dan untuk menguji alat ukur dalam penelitian ini berupa kuesioner, dengan diuji validitasnya berarti dapat menunjukan sejauh mana suatu alat yang diujikan dalam penelitian yang memenuhi standar dari ketersesuaian dalam pengukurannya. Adapun untuk mengukur mengenai validitas kuesioner menggunakan metode korelasi pearson product moment dimana hasil yang didapat dari kuesioner penelitiannya berupa data/skor yang dikorelasikan. Valid atau tidak validnya alat ukur tersebut dapat diuji dengan penjumlahan semua nilai/skor yang didapat dari hasil penelitian yang apabila korelasi antara nilai/skor total masing-masing dari pernyataan dalam kuesioner signifikan, maka demikian dapat dikatakan bahwa alat pengukur dari penelitian ini dikatakan valid. Hasil penelitian yang diperoleh, kemudian dihitung mengenai korelasi dari masing-masing item, lalu setelah itu hasil perhitungan dari $\mathrm{r}_{\text {hitung }}$ kemudian dibandingkan dengan $\mathrm{r}_{\text {tabel }}$ dengan taraf nyata $(\alpha)$ yaitu $5 \%, \mathrm{r}_{\text {tabel }}$ menggunakan cut of point 0,3 dengan kriteria penelitiannya yaitu jika nilainya lebih besar dari 0,300 maka dianggap valid, Sugiyono (2006). Berdasarkan hasil perhitungan dengan menggunakan SPSS seri 20, maka dapat diperoleh hasilnya sebagai berikut.

\section{Uji Validitas Variabel Rotasi}

Berdasarkan kajian dari teori mengenai rotasi pekerjaan yang telah diperoleh menjadi 3 dimensi kemudian diturunkan kembali menjadi 6 indikator penelitiannya yang dijadikan pernyataan dalam bentuk keusioner yang diberikan kepada 85 dari 90 responden untuk menjawabnya. hasilnya dapat dilihat sebagai berikut:

Tabel 1.1

Hasil Uji Validitas Variabel Rotasi

\begin{tabular}{|c|c|c|c|}
\hline No Item & r-hitung & r-kritis & Kesimpulan \\
\hline 1 & 0,838 & 0,300 & Valid \\
\hline 2 & 0,809 & 0,300 & Valid \\
\hline 3 & 0,868 & 0,300 & Valid \\
\hline 4 & 0,889 & 0,300 & Valid \\
\hline 5 & 0,796 & 0,300 & Valid \\
\hline 6 & 0,846 & 0,300 & Valid \\
\hline
\end{tabular}


Sumber : Data primer yang diolah, 2014

Berdasarkan dari tabel tersebut, maka kuesioner mengenai rotasi yang terdiri dari 3 dimensi dan diturunkan ke dalam 6 indikator sebanyak 6 pernyataan, semua penyataan valid karena nilai $\mathbf{r}_{\text {hitung }}$ lebih besar dari nilai $\mathbf{r}_{\text {kritis }}$ yaitu 0,3 . Hal ini menunjukan indikasi bahwa seluruh option jawaban dari responden dinyatakan valid.

\section{Uji Validitas Variabel Kompetensi}

Merujuk pada kajian teori mengenai kompetensi karyawan yang telah diperoleh 5 dimensi yang diturunkan menjadi 12 indikator, dimana kemudian dijadikan keusioner berupa pernyataan yang diajukan ke responden untuk dijawab. Setelah itu, maka penulis melakukan pengecekan terhadap kuesioner yang masuk serta dilakukan perhitungan dengan cara mengkorelasikan nilai/skor dari setiap butir kuesioner pada pernyataannya dengan jumlah nilai/skor, maka hasilnya didapat sebagai berikut:

Tabel 1.2

Hasil Uji Validitas Variabel Kompetensi

\begin{tabular}{|c|c|c|c|c|c|c|c|}
\hline $\begin{array}{c}\text { No } \\
\text { Item }\end{array}$ & $\begin{array}{c}\text { r- } \\
\text { hitung }\end{array}$ & r-tabel & Kesimpulan & $\begin{array}{c}\text { No } \\
\text { Item }\end{array}$ & $\begin{array}{c}\text { r- } \\
\text { hitung }\end{array}$ & r-tabel & Kesimpulan \\
\hline 1 & 0,865 & 0,300 & Valid & 7 & 0,840 & 0,300 & Valid \\
\hline 2 & 0,830 & 0,300 & Valid & 8 & 0,896 & 0,300 & Valid \\
\hline 3 & 0,898 & 0,300 & Valid & 9 & 0,883 & 0,300 & Valid \\
\hline 4 & 0,911 & 0,300 & Valid & 10 & 0,881 & 0,300 & Valid \\
\hline 5 & 0,906 & 0,300 & Valid & 11 & 0,378 & 0,300 & Valid \\
\hline 6 & 0,840 & 0,300 & Valid & 12 & 0,684 & 0,300 & Valid \\
\hline
\end{tabular}

Sumber : Data primer yang diolah, 2014

Berdasarkan dari tabel tersebut, maka kuesioner mengenai kompetensi yang terdiri dari 5 dimensi dan diturunkan ke dalam 12 indikator sebanyak 12 pernyataan, semua penyataan valid karena nilai $\mathrm{r}_{\text {hitung }}$ lebih besar dari nilai $\mathrm{r}_{\text {kritis }}$ yaitu 0,3 . Hal ini menunjukan indikasi bahwa seluruh option jawaban dari responden dinyatakan valid. 


\section{Uji Validitas Variabel Motivasi}

Merujuk pada kajian teori mengenai motivasi karyawan yang telah diperoleh 6 dimensi yang diturunkan menjadi 12 indikator, kemudian dijadikan keusioner berupa pernyataan yang diajukan ke responden untuk dijawab. Setelah itu, dilakukan pengecekan terhadap kuesioner yang masuk serta dilakukan perhitungan dengan cara mengkorelasikan nilai/skor dari setiap butir kuesioner pada pernyataannya dengan jumlah nilai/skor, maka hasilnya didapat sebagai berikut:

Tabel 1.3

Hasil Uji Validitas Variabel Motivasi

\begin{tabular}{|c|c|c|c|c|c|c|c|}
\hline $\begin{array}{c}\text { No } \\
\text { Item }\end{array}$ & $\begin{array}{c}\text { r- } \\
\text { hitung }\end{array}$ & $\begin{array}{c}\text { r- } \\
\text { tabel }\end{array}$ & Kesimpulan & $\begin{array}{c}\text { No } \\
\text { Item }\end{array}$ & $\begin{array}{c}\text { r- } \\
\text { hitung }\end{array}$ & $\begin{array}{c}\text { r- } \\
\text { tabel }\end{array}$ & Kesimpulan \\
\hline 1 & 0,721 & 0,300 & Valid & 7 & 0,414 & 0,300 & Valid \\
\hline 2 & 0,761 & 0,300 & Valid & 8 & 0,835 & 0,300 & Valid \\
\hline 3 & 0,651 & 0,300 & Valid & 9 & 0,786 & 0,300 & Valid \\
\hline 4 & 0,830 & 0,300 & Valid & 10 & 0,748 & 0,300 & Valid \\
\hline 5 & 0,544 & 0,300 & Valid & 11 & 0,732 & 0,300 & Valid \\
\hline 6 & 0,625 & 0,300 & Valid & 12 & 0,410 & 0,300 & Valid \\
\hline
\end{tabular}

Sumber : Data primer yang diolah, 2014

Berdasarkan dari tabel tersebut, maka kuesioner mengenai motivasi yang terdiri dari 6 dimensi dan diturunkan ke dalam 12 indikator sebanyak 12 pernyataan, semua penyataan valid karena nilai $\mathrm{r}_{\text {hitung }}$ lebih besar dari nilai $\mathrm{r}_{\text {tabel }}$ yaitu 0,3 . Hal ini menunjukan indikasi bahwa seluruh option jawaban dari responden dinyatakan valid.

\section{Uji Reliabilitas}

Adapun alat ukur pada penelitian ini, penulis menggunakan kuesioner tertutup, dimana kehandalan (reliabel) suatu alat ukur berarti kemampuan alat ukur yang menjadi pegangan penulis dalam melakukan penelitian ini dapat mengukur gejala yang diteliti secara konsisten. Untuk dapat mengukur tingkat kehandalan alat ukur dalam penelitian ini menggunakan alat ukur secara interval, digunakan nilai alpha cronbach. Dimana suatu nilai instrumen dapat dikatakan handal (reliabel) apabila memenuhi syarat dengan memiliki koefisien kehandalan atau alpha sebesar 0,700 . 
Tabel 1.5

Hasil Uji Reliabelitas Keseluruhan Variabel

\begin{tabular}{|c|c|c|c|}
\hline Variabel & r-hitung & r-kritis & Kesimpulan \\
\hline Rotasi Pegawai $\left(\mathrm{X}_{1}\right)$ & 0,914 & 0,700 & Reliabel \\
\hline Kompetensi $\left(\mathrm{X}_{2}\right)$ & 0,955 & 0,700 & Reliabel \\
\hline Motivasi $(\mathrm{Y})$ & 0,875 & 0,700 & Reliabel \\
\hline
\end{tabular}

Sumber : Data primer yang diolah, 2014

Berdasarkan hasil uji reliabelitas tersebut didapat nilai Alpha Cronbach untuk nilai koefisien reliabilitas pada instrumen (kuesioner) penelitian berada antara 0,800 sampai dengan 0,900 dimana artinya bahwa hasil tersebut menunjukan nilai “Alpha Cronbach" lebih besar dari 0,700 yang mengartikan bahwa keseluruhan dari variabel pada penelitian ini dapat dinyatakan reliabel atau dengan kata lain memenuhi persyaratan.

\section{Analisis Pada Variabel Penelitian}

\section{Variabel Rotasi}

Variabel rotasi pada penelitian ini diukur dengan 6 item dari 3 dimensi, yaitu Adapun gambaran dari jawaban responden terhadap indikator-indikator dalam penelitian ini yang mengukur mengenai variabel rotasi $\left(\mathrm{X}_{1}\right)$ perhitungan nilai ratarata yang merujuk kepada Supranto, (2000 : 64) dimana jika nilai rata-rata diatas 7 , maka kategori indikator tersebut dapat dikatakan baik. Berdasarkan hasil pengumpulan data, dimana penulis mengacu pada kuesioner yang dijadikan sebagai instrumen penelitian yang diperoleh skor/nilai rentang skor/nilai data untuk variabel rotasi yang diwakili dengan 6 item pernyataan dimana yang dijawab oleh 85 responden. Selain itu merujuk data dari analisis statistik yang menyatakan variabel rotasi dan atau indikator penelitian dapat dinyatakan valid dan memiliki reliabilitas, sehingga penulis selanjutnya melakukan deskriptif analisis yang mengacu pada nilai rata-rata yang didapatkan pada perhitungan yang telah penulis lakukan. Adapun rekapitulasi dari hasil penelitian dari kuesioner yang diminta untuk dijawab oleh responden yaitu sebagai berikut: 
Tabel 1.6

Rekapitulasi Jawaban Mengenai Rotasi

\begin{tabular}{|c|c|c|c|c|c|c|c|c|c|c|c|c|c|c|}
\hline \multirow{2}{*}{ No } & \multirow{2}{*}{ Penyataan Negatif } & \multicolumn{10}{|c|}{ Skala Penilaian } & \multirow{2}{*}{ Pernyataan Positif } & \multirow{2}{*}{$\begin{array}{l}\text { Rata- } \\
\text { Rata }\end{array}$} & \multirow{2}{*}{ Varians } \\
\hline & & 1 & 2 & 3 & 4 & 5 & 6 & 7 & 8 & 9 & 10 & & & \\
\hline 1 & $\begin{array}{l}\text { Rotasi pekerjaan sangat } \\
\text { tidak berpengaruh yang } \\
\text { signifikan } \\
\text { kemampuan kerja yang } \\
\text { baru. }\end{array}$ & 1 & 2 & 2 & 2 & 6 & 6 & 20 & 25 & 17 & 4 & $\begin{array}{lr}\text { Rotasi pekerjaan } & \text { sangat } \\
\text { berpengaruh } & \text { yang } \\
\text { signifikan } & \text { terhadap } \\
\text { kemampuan kerja yang } \\
\text { baru. }\end{array}$ & 7,27 & 3,44 \\
\hline 2 & $\begin{array}{l}\text { Rotasi pekerjaan bukan } \\
\text { memberikan variasi } \\
\text { pengalaman bekerja }\end{array}$ & 1 & 1 & 2 & 0 & 6 & 9 & 19 & 23 & 19 & 5 & $\begin{array}{ll}\text { Rotasi pekerjaan } & \text { sangat } \\
\text { memberikan } & \text { variasi } \\
\text { pengalaman bekerja } & \end{array}$ & 7,42 & 3,03 \\
\hline 3 & $\begin{array}{l}\text { Rotasi pekerjaan sangat } \\
\text { tidak memiliki keterkaitan } \\
\text { untuk dapat memberikan } \\
\text { pengetahuan berbagai } \\
\text { jenis pekerjaan }\end{array}$ & 0 & 3 & 4 & 0 & 5 & 12 & 14 & 25 & 15 & 7 & $\begin{array}{l}\text { Rotasi pekerjaan sangat } \\
\text { memiliki keterkaitan untuk } \\
\text { dapat memberikan } \\
\text { pengetahuan berbagai jenis } \\
\text { pekerjaan }\end{array}$ & 7,27 & 3,72 \\
\hline 4 & $\begin{array}{l}\text { Kebijakan rotasi sangat } \\
\text { tidak memiliki keterkaitan } \\
\text { untuk dapat memberikan } \\
\text { keterampilan kerja yang } \\
\text { baru }\end{array}$ & 0 & 1 & 0 & 1 & 4 & 7 & 16 & 22 & 19 & 15 & $\begin{array}{l}\text { Kebijakan rotasi sangat } \\
\text { memiliki keterkaitan untuk } \\
\text { dapat memberikan } \\
\begin{array}{l}\text { keterampilan } \\
\text { baru }\end{array}\end{array}$ & 7,96 & 2,51 \\
\hline 5 & $\begin{array}{l}\text { Rotasi kerja sangat tidak } \\
\text { baik dalam mengatasi } \\
\text { kejenuhan saya bekerja }\end{array}$ & 0 & 4 & 0 & 5 & 7 & 14 & 11 & 20 & 13 & 11 & $\begin{array}{l}\text { Rotasi kerja sangat baik } \\
\text { dalam mengatasi kejenuhan } \\
\text { saya bekerja }\end{array}$ & 7,19 & 4,23 \\
\hline
\end{tabular}




\begin{tabular}{|c|c|c|c|c|c|c|c|c|c|c|c|c|c|c|}
\hline 6 & $\begin{array}{l}\text { Rotasi tidak memiliki nilai } \\
\text { yang positif untuk dapat } \\
\text { menambah semangat kerja }\end{array}$ & 0 & 3 & 6 & 3 & 7 & 10 & 12 & 18 & 15 & 11 & $\begin{array}{l}\text { Rotasi memiliki nilai yang } \\
\text { positif untuk dapat } \\
\text { menambah semangat kerja }\end{array}$ & 7,11 & 4,91 \\
\hline & Prosentase & \multicolumn{6}{|c|}{$17,00 \%$} & \multicolumn{4}{|c|}{$83,00 \%$} & & & \\
\hline & Jumlah & 2 & 14 & 14 & 11 & 35 & 58 & 92 & 133 & 98 & 53 & & & \\
\hline & Jumlah x Bobot & 2 & 28 & 42 & 44 & 175 & 348 & 644 & 1064 & 882 & 530 & & & \\
\hline & Total & \multicolumn{10}{|c|}{3759} & & & \\
\hline & Rata-Rata & \multicolumn{10}{|c|}{7,37} & & & \\
\hline & Standar Deviasi & \multicolumn{10}{|c|}{1,92} & & & \\
\hline & Kategori & \multicolumn{10}{|c|}{ Baik } & & & \\
\hline
\end{tabular}


Dari Tabel 1.6 dapat dilihat dan dijelaskan bahwa hasil perhitungan nilai indeks terhadap variabel rotasi, menunjukan bahwa variabel Rotasi memiliki indeks sebesar 3759. Dari indikator mengenai rotasi terdapat nilai indeks paling tinggi yaitu pengetahuan karyawan sebesar 7,96 serta secara berturut-turut nilai indek dari masing-masing indikator tersebut yaitu kejenuhan kerja dari keseluruhan indikator tersebut, indikator yang menyatakan bahwa "rotasi pegawai memiliki positif untuk dapat menambah semangat kerja" sebesar 7,11. Terdapat indikator yang memiliki nilai terkecil hendaknya dapat menjadi bahan pertimbangan dan hal yang perlu diperbaiki dan tentunya dapat ditingkatkan. Secara keseluruhan dari perhitungan semua indikator tersebut rotasi atau kecenderungan proses rotasi di STEI ITB sudah optimal.

Pada hasil perhitungan rata-rata untuk indikator yang menyatakan "Kebijakan rotasi sangat memiliki keterkaitan untuk dapat memberikan keterampilan kerja yang baru" memiliki nilai rata-rata paling besar dengan nilainya sebesar 7,96 dan memiliki nilai varian yang paling kecil dibandingkan dengan berbagai indikator lainnya yaitu sebesar 2,51. Hal ini menjadi temuan dalam penelitian yang penulis lakukan dimana terdapat nilai paling tinggi dan paling kecil. Pada perhitungan keseluruhan dari yang menjawab dengan nilai antara 1-6 yang merupakan penilaian yang cenderung ke arah negatif dan atau responden menilai tidak ditemukan jawaban responden sebesar 17,00\%. Hasil ini juga penulis simpulkan terdapat karyawan yang merasa cenderung mengharapkan pada proses rotasi dapat memberikan efek yang positif kepada mereka. Sementara indikator pada "Rotasi memiliki nilai yang positif untuk dapat menambah semangat kerja" sebesar 4,91 dengan nilai rata-rata sebesar 7,11. Dapat diartikan rotasi yang seharusnya memiliki nilai yang positif untuk dapat menambah semangat kerja.

\section{Variabel Kompetensi}

Variabel kompetensi pada penelitian ini diukur dengan dua belas item item dari dimensi-dimensi guna mendukung penelitian ini. Adapun gambaran dari jawaban responden terhadap indikator-indikator dalam penelitian ini yang mengukur mengenai variabel kompetensi $\left(\mathrm{X}_{2}\right)$ untuk pertanyaan No. 7 - 18 dan berdasarkan 
perhitungan nilai rata-rata yang merujuk kepada Supranto, (2000 : 64) dimana jika nilai rata-rata diatas 7 , maka kategori indikator tersebut dapat dikatakan baik dan atau sebaliknya.

Berdasarkan hasil pengumpulan data dari 85 responden. Selain itu merujuk data dari analisis statistik yang menyatakan variabel kompetensi dan atau dari indikator penelitian dapat dinyatakan valid dan memiliki reliabilitas seperti yang sudah dibahas pada pokok pembahasan diatas lainnya. Setelah itu penulis selanjutnya melakukan analisis deskriptif yang mengacu pada nilai indek raihan rata-rata yang didapatkan pada perhitungan yang telah penulis lakukan. Adapun rekapitulasi dari hasil penelitian dari kuesioner yang diminta untuk dijawab oleh responden yaitu sebagai berikut: 
Tabel 1.7

Rekapitulasi Jawaban Mengenai Kompetensi

\begin{tabular}{|c|c|c|c|c|c|c|c|c|c|c|c|c|c|c|}
\hline \multirow{2}{*}{ No } & \multirow{2}{*}{ Penyataan Negatif } & \multicolumn{10}{|c|}{ Skala Penilaian } & \multirow{2}{*}{ Pernyataan Positif } & \multirow{2}{*}{$\begin{array}{l}\text { Rata- } \\
\text { Rata }\end{array}$} & \multirow{2}{*}{ Varians } \\
\hline & & 1 & 2 & 3 & 4 & 5 & 6 & 7 & 8 & 9 & 10 & & & \\
\hline 7 & $\begin{array}{l}\text { Pengetahuan saya sangat } \\
\text { tidak memiliki } \\
\text { ketersesuaian pekerjaan }\end{array}$ & 0 & 2 & 0 & 2 & 7 & 10 & 15 & 15 & 25 & 9 & $\begin{array}{l}\text { Pengetahuan saya sangat } \\
\text { sesuai dengan pekerjaan }\end{array}$ & 7,61 & 3,22 \\
\hline 8 & $\begin{array}{l}\text { Dengan tidak memiliki } \\
\text { pengetahuan, saya sangat } \\
\text { tidak dapat menyelesaikan } \\
\text { pekerjaan dengan cepat }\end{array}$ & 0 & 2 & 4 & 0 & 3 & 9 & 15 & 24 & 20 & 8 & $\begin{array}{l}\text { Dengan memiliki } \\
\text { pengetahuan, saya sangat } \\
\text { dapat menyelesaikan } \\
\text { pekerjaan dengan cepat }\end{array}$ & 7,55 & 3,39 \\
\hline 9 & 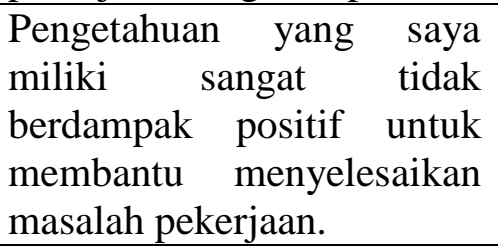 & 0 & 2 & 0 & 2 & 3 & 5 & 16 & 22 & 25 & 10 & $\begin{array}{l}\text { Pengetahuan yang saya } \\
\text { miliki sangat berdampak } \\
\text { positif untuk membantu } \\
\text { menyelesaikan masalah } \\
\text { pekerjaan. }\end{array}$ & 7,88 & 2,75 \\
\hline 10 & $\begin{array}{lr}\text { Keterampilan } & \text { sangat tidak } \\
\text { berpengaruh } & \text { terhadap } \\
\text { keterseseuaian } & \text { dengan } \\
\text { pekerjaan. } & \\
\end{array}$ & 0 & 3 & 0 & 0 & 2 & 5 & 17 & 26 & 24 & 8 & $\begin{array}{lr}\text { Keterampilan } & \text { sangat } \\
\text { berpengaruh } & \text { terhadap } \\
\text { keterseseuaian } & \text { dengan } \\
\text { pekerjaan. } & \\
\end{array}$ & 7,87 & 2,59 \\
\hline 11 & $\begin{array}{l}\text { Keterampilan yang saya } \\
\text { miliki tidak serta merta } \\
\text { dapat dengan mudah } \\
\text { menyelesaikan pekerjaan di } \\
\text { kantor. }\end{array}$ & 0 & 1 & 0 & 0 & 4 & 5 & 11 & 26 & 26 & 12 & $\begin{array}{l}\text { Keterampilan yang saya } \\
\text { miliki, dapat dengan } \\
\text { mudah menyelesaikan } \\
\text { pekerjaan di kantor. }\end{array}$ & 8,13 & $\angle, U Y$ \\
\hline 12 & $\begin{array}{l}\text { Komunikasi dalam bekerja } \\
\text { saya sangat buruk terhadap } \\
\text { sesama rekan kerja. }\end{array}$ & 0 & 3 & 0 & 0 & 4 & 3 & 12 & 26 & 27 & 10 & $\begin{array}{l}\text { Komunikasi dalam } \\
\text { bekerja saya sangat baik } \\
\text { trhdp sesama rekan kerja. }\end{array}$ & 7,99 & 2,80 \\
\hline
\end{tabular}




\begin{tabular}{|c|c|c|c|c|c|c|c|c|c|c|c|c|c|c|}
\hline 13 & $\begin{array}{l}\text { Saya tidak perah bertanya } \\
\text { ke rekan kerja cara } \\
\text { mengatasi pekerjaan sulit }\end{array}$ & 0 & 1 & 0 & 0 & 3 & 3 & 16 & 20 & 28 & 14 & $\begin{array}{l}\text { Saya selalu bertanya ke } \\
\text { rekan kerja mengenai cara } \\
\text { mengatasi pekerjaan sulit }\end{array}$ & 8,22 & 2,03 \\
\hline 14 & 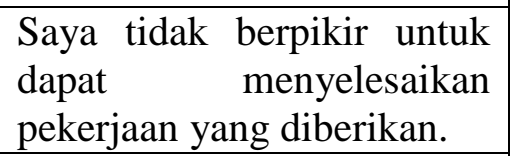 & 0 & 2 & 0 & 0 & 2 & 6 & 8 & 25 & 29 & 13 & $\begin{array}{l}\text { Saya dapat menyelesaikan } \\
\text { pekerjaan yang diberikan. }\end{array}$ & 8,20 & 2,38 \\
\hline 15 & $\begin{array}{lll}\text { Saya sangat } & \text { tidak } \\
\text { menghormati rekan } & \text { kerja } \\
\text { ditempat bekerja } & \\
\end{array}$ & 0 & 1 & 0 & 0 & 3 & 5 & 11 & 19 & 32 & 14 & $\begin{array}{l}\text { Saya sangat menghormati } \\
\text { rekan kerja ditempat } \\
\text { bekerja }\end{array}$ & 8,28 & 2,09 \\
\hline 16 & $\begin{array}{l}\text { Saya sangat tidak peduli } \\
\text { untuk membantu rekan } \\
\text { kerja yang membutuhkan } \\
\text { bantuan dalam bekerja }\end{array}$ & 0 & 1 & 0 & 0 & 6 & 5 & 12 & 19 & 28 & 14 & $\begin{array}{l}\text { Saya sangat peduli untuk } \\
\text { membantu rekan kerja } \\
\text { yang membutuhkan } \\
\text { bantuan dalam bekerja }\end{array}$ & 8,12 & 2,44 \\
\hline 17 & $\begin{array}{l}\text { Saya tidak pernah } \\
\text { mendapatkan upah secara } \\
\text { adil dan layak dari tempat } \\
\text { saya bekerja }\end{array}$ & 0 & 0 & 3 & 0 & 5 & 6 & 17 & 16 & 30 & 8 & $\begin{array}{l}\text { Saya mendapatkan upah } \\
\text { sangat adil dan sangat } \\
\text { layak dari tempat saya } \\
\text { bekerja }\end{array}$ & 7,85 & 2,63 \\
\hline 18 & $\begin{array}{l}\text { Tempat kerja sangat tidak } \\
\text { menyenangkan }\end{array}$ & 0 & 0 & 2 & 1 & 4 & 11 & 17 & 21 & 22 & 7 & $\begin{array}{l}\text { Tempat kerja sangat } \\
\text { menyenangkan }\end{array}$ & 7,66 & 2,42 \\
\hline & Prosentase & \multicolumn{6}{|c|}{$8,76 \%$} & \multicolumn{4}{|c|}{$91,24 \%$} & & & \\
\hline & Jumlah & 0 & 5 & 5 & 1 & 23 & 36 & 81 & 120 & 169 & 70 & & & \\
\hline & Jumlah x Bobot & 0 & 10 & 15 & 4 & 115 & 216 & 567 & 960 & 1521 & 700 & & & \\
\hline & Total & \multicolumn{10}{|c|}{4108} & & & \\
\hline & Rata-Rata & \multicolumn{10}{|c|}{7,95} & & & \\
\hline & Standar Deviasi & \multicolumn{10}{|c|}{1,61} & & & \\
\hline & Kategori & \multicolumn{10}{|c|}{ Baik } & & & \\
\hline
\end{tabular}


Dari hasil perhitungan nilai indeks terhadap variabel kompetensi sebesar 4108 sehingga dapat disimpulkan bahwa kecenderungan kompetensi berada pada kategori baik. Terdapat indikator yang memiliki nilai indeks paling tinggi yaitu karakteristik pribadi sebesar 8,28. Terdapat pula indikator yang menyatakan bahwa "dengan tidak memiliki pengetahuan, karyawan tidak dapat menyelesaikan pekerjaan dengan cepat" memiliki nilai indeks yang paling rendah dibandingkan indikator yang lainnya hanya sebesar 7,55. Penulis menyimpulkan bahwa kecenderungan kompetensi di STEI ITB sudah optimal. Hal itu juga tercermin dari hasil perhitungang rata-rata yang memiliki bobot yang sangat baik.

Pada indikator "Saya selalu bertanya ke rekan kerja mengenai cara mengatasi pekerjaan yang sulit" sebesar 8,22 dengan nilai varians paling rendah yaitu sebesar 2,03. Pada posisi tersebut memiliki nilai rata-rata yang tinggi dan nilai varians yang kecil. Selain itu indikator "Dengan memiliki pengetahuan, saya sangat dapat menyelesaikan pekerjaan dengan cepat" mendapatkan nilai varians yang paling besar dengan nilai sebesar 3,39 sedangkan nilai perhitungan rata-rata sebaliknya yaitu paling rendah dibandingkan indikator yang lainnya. Pada penelitian ini juga penulis mendapati nilai perhitungan secara keseluruhan dimana para responden menjawab kearah yang cenderung ke negatif untuk variabel kompetensi. Dimana perhitungan nilai keseluruhan sebesar $8,76 \%$. Walaupun secara perhitungan tidak terlalu besar namun hendaknya temuan ini mendapati bahwa kompetensi yang dimiliki karyawan cenderung perlu ditingkatkan. Angka tersebut merupakan gambaran dari kompetensi yang dimiliki karyawan saat ini masih belum sesuai harapan yang mereka inginkan.

\section{Variabel Motivasi}

Berdasarkan hasil pengumpulan data, dimana penulis mengacu pada kuesioner yang dijadikan sebagai instrumen penelitian yang diperoleh skor/nilai dengan rentang skor/nilai data untuk variabel motivasi yang diwakili dengan enam dimensi dan dua belas item indikator yang sajikan dalam bentuk pernyataan dimana kuesioner tersebut dijawab oleh 85 responden. Selain itu merujuk data dari analisis statistik yang menyatakan variabel motivasi dan atau dari indikator penelitian dapat 
dinyatakan valid dan memiliki reliabilitas seperti yang sudah dibahas pada pokok pembahasan diatas lainnya. Pada proses analisis secara deskriptif, penulis menjabarkan dari indikator yang diteliti serta dengan melihat nilai rata-rata dari setiap menjadikan penulis pembahasan detail terhadap efek dari penggunaan kuesioner dalam penelitian ini. Pada prosepek pengukuran rata-rata, penulis mengacu pada pendapat Supranto, (2000 : 64). Gambaran dari hasil pengumpulan data penulis rangkum dan sajikan dalam bentuk tabel untuk memudahkan penyusunan penelitian ini. Adapun gambaran dari jawaban responden terhadap indikator-indikator dalam penelitian ini yang mengukur mengenai variabel Motivasi (Y) untuk pertanyaan No. 19 - 30 dan berdasarkan perhitungan nilai indeks dapat dilihat seperti tabel 1.8 sebagai berikut: 
Tabel 1.8

Rekapitulasi Jawaban Mengenai Motivasi

\begin{tabular}{|c|c|c|c|c|c|c|c|c|c|c|c|c|c|c|}
\hline \multirow{2}{*}{ No } & \multirow{2}{*}{ Penyataan Negatif } & \multicolumn{10}{|c|}{ Skala Penilaian } & \multirow{2}{*}{ Pernyataan Positif } & \multirow{2}{*}{$\begin{array}{l}\text { Rata- } \\
\text { Rata }\end{array}$} & \multirow{2}{*}{ Varians } \\
\hline & & 1 & 2 & 3 & 4 & 5 & 6 & 7 & 8 & 9 & 10 & & & \\
\hline 19 & $\begin{array}{l}\text { Prestasi kerja yang saya raih } \\
\text { saat ini sangat tidak dapat } \\
\text { memuaskan hati }\end{array}$ & 0 & 0 & 1 & 1 & 6 & 8 & 20 & 25 & 17 & 7 & $\begin{array}{l}\text { Prestasi kerja yang saya raih } \\
\text { saat ini sangat memuaskan }\end{array}$ & 7,62 & 2,14 \\
\hline 20 & $\begin{array}{l}\text { Saya tidak pernah mendapatkan } \\
\text { bonus atas prestasi yang sudah } \\
\text { saya lakukan. }\end{array}$ & 0 & 2 & 2 & 0 & 8 & 9 & 21 & 23 & 13 & 7 & $\begin{array}{l}\text { Saya mendapatkan bonus yang } \\
\text { besar atas prestasi yang sudah } \\
\text { saya lakukan. }\end{array}$ & 7,32 & 3,01 \\
\hline 21 & $\begin{array}{l}\text { Perhatian atas pekerjaan yang } \\
\text { telah terselesaikan senantiasa } \\
\text { tidak pernah berdampak positif } \\
\text { bagi saya }\end{array}$ & 0 & 0 & 2 & 1 & 7 & 8 & 15 & 19 & 20 & 13 & $\begin{array}{l}\text { Perhatian atas pekerjaan yang } \\
\text { telah terselesaikan senantiasa } \\
\text { berdampak positif bagi saya }\end{array}$ & 7,76 & 2,90 \\
\hline 22 & $\begin{array}{lcr}\text { Pimpinan saya, sangat } & \text { tidak } \\
\text { peduli apalagi } & \text { bisa } \\
\text { membangkitkan } & \text { semangat } \\
\text { bekerja } & & \\
\end{array}$ & 0 & 0 & 2 & 1 & 8 & 9 & 13 & 20 & 22 & 10 & $\begin{array}{l}\text { Pimpinan saya, sangat peduli } \\
\text { tentunya bisa membangkitkan } \\
\text { semangat bekerja }\end{array}$ & 7,68 & 2,86 \\
\hline 23 & $\begin{array}{l}\text { Saya merasa sangat tidak } \\
\text { bangga menjadi bagian dari } \\
\text { STEI ITB }\end{array}$ & 0 & 0 & 0 & 1 & 2 & 9 & 12 & 19 & 28 & 14 & $\begin{array}{l}\text { Saya merasa sangat bangga } \\
\text { menjadi bagian dari STEI ITB }\end{array}$ & 8,19 & 1,94 \\
\hline 24 & $\begin{array}{l}\text { Saya merasa sangat tidak betah } \\
\text { selama bekerja di STEI ITB }\end{array}$ & 0 & 0 & 0 & 2 & 3 & 9 & 18 & 16 & 24 & 13 & $\begin{array}{l}\text { Saya merasa sangat betah } \\
\text { selama bekerja di STEI ITB }\end{array}$ & 7,96 & 2,25 \\
\hline 25 & $\begin{array}{l}\text { Saya tidak peduli apalagi dapat } \\
\text { menyelesaikan pekerjaan } \\
\text { dengan penuh tanggung jawab }\end{array}$ & 0 & 0 & 1 & 0 & 3 & 7 & 13 & 22 & 28 & 11 & $\begin{array}{lr}\text { Saya sangat } & \text { dapat } \\
\text { menyelesaikan } & \text { pekerjaan } \\
\text { dengan penuh tanggung jawab }\end{array}$ & 8,11 & 1,95 \\
\hline
\end{tabular}




\begin{tabular}{|c|c|c|c|c|c|c|c|c|c|c|c|c|c|c|}
\hline 26 & $\begin{array}{l}\text { Saya tidak akan menyelesaikan } \\
\text { pekerjaan yang diberikan } \\
\text { karena tidak mendapatkan } \\
\text { imbalan yg sesuai beban kerja. }\end{array}$ & 0 & 0 & 0 & 1 & 6 & 12 & 13 & 25 & 20 & 8 & $\begin{array}{l}\text { Saya akan menyelesaikan } \\
\text { pekerjaan yang diberikan } \\
\text { karena mendapatkan imbalan } \\
\text { yang sesuai dengan beban kerja. }\end{array}$ & 7,73 & 2,10 \\
\hline 27 & $\begin{array}{l}\text { Kemampuan yang saya miliki, } \\
\text { tidak pernah diperhatikan } \\
\text { selama bekerja. }\end{array}$ & 0 & 0 & 0 & 0 & 5 & 12 & 12 & 27 & 21 & 8 & $\begin{array}{l}\text { Kemampuan yang saya miliki } \\
\text { selalu diperhatikan selama } \\
\text { bekerja. }\end{array}$ & 7,84 & 1,85 \\
\hline 28 & $\begin{array}{lr}\text { Selama bekerja, saya tidak } \\
\text { mungkin } & \text { mendapatkan } \\
\text { pelatihan } & \text { guna } \\
\text { mengembangkan } & \text { keahlian } \\
\text { untuk kemajuan dalam bekerja. }\end{array}$ & 3 & 0 & 0 & 5 & 8 & 3 & 20 & 26 & 14 & 6 & $\begin{array}{l}\text { Selama bekerja, saya selalu } \\
\text { mendapatkan pelatihan guna } \\
\text { mengembangkan keahlian untuk } \\
\text { kemajuan saya dalam bekerja. }\end{array}$ & 7,24 & 3,80 \\
\hline 29 & $\begin{array}{l}\text { Tempat saya bekerja belum } \\
\text { pernah } \\
\text { kesempatan jenjang karir yang } \\
\text { sangat baik }\end{array}$ & 1 & 1 & 1 & 1 & 6 & 8 & 13 & 28 & 20 & 6 & 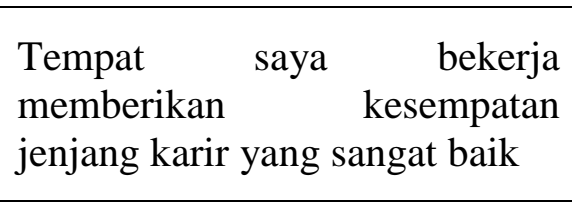 & 7,56 & 3,01 \\
\hline 30 & $\begin{array}{l}\text { Saya sangat tidak mungkin } \\
\text { mendapatkan beasiswa untuk } \\
\text { meningkatkan pendidikan. }\end{array}$ & 3 & 4 & 4 & 4 & 11 & 10 & 8 & 21 & 14 & 6 & $\begin{array}{l}\text { Saya selalu mendapatkan } \\
\text { beasiswa untuk meningkatkan } \\
\text { pendidikan. }\end{array}$ & 6,64 & 5,73 \\
\hline & Prosentase & \multicolumn{6}{|c|}{$15,28 \%$} & \multicolumn{4}{|c|}{$84,72 \%$} & & & \\
\hline & Jumlah & 7 & 5 & 6 & 11 & 39 & 52 & 79 & 149 & 117 & 45 & & & \\
\hline & Jumlah x Bobot & 7 & 10 & 18 & 44 & 195 & 312 & 553 & 1192 & 1053 & 450 & & & \\
\hline & Total & \multicolumn{10}{|c|}{3834} & & & \\
\hline & Rata-Rata & \multicolumn{10}{|c|}{7,64} & & & \\
\hline & Standar Deviasi & \multicolumn{10}{|c|}{1,71} & & & \\
\hline & Kategori & \multicolumn{10}{|c|}{ Baik } & & & \\
\hline
\end{tabular}

Sumber : Data primer yang diolah, 2014 
Dari tabel tersebut dapat dilihat dan dijelaskan bahwa hasil perhitungan nilai indeks terhadap variabel motivasi, menunjukan bahwa variabel motivasi memiliki indeks sebesar 3834 sehingga dapat disimpulkan bahwa kecenderungan motivasi dari indikator-indikator penelitiannya berada pada kategori baik. Dari indikator yang penulis gunakan dalam meneliti mengenai motivasi terdapat indikator yang memiliki nilai indeks paling tinggi yaitu kebanggan bekerja sebesar 8,19 serta secara berturutturut nilai indek dari masing-masing indikator tersebut yaitu senang bekerja dari keseluruhan indikator tersebut. Namun pada pengukuran indikator yang menyatakan bahwa "pegawai mungkin mendapatkan beasiswa untuk meningkatkan pendidikan" memiliki nilai indeks yang paling rendah dibandingkan indikator yang lainnya yaitu hanya sebesar 6,64 .

Dari hasil perhitungan tersebut, penulis mendapati indikator yang menjadi perhatian tersendiri karena memiliki nilai rata-rata yang paling tinggi yaitu sebesar 8,19 sedangkan nilai variansnya yang terkecil yaitu sebesar 1,94 yaitu pada indikator "Saya merasa sangat bangga menjadi bagian dari STEI ITB" dari hasil penelitian ini dan melihat hasil perhitungan baik rata-rata maupun nilai variansnya merupakan kondisi yang ideal karena memiliki nilai rata-rata yang tingggi sedangkan nilai varians terendah. Indikator yang menjadi pertimbangan yang menyatakan "Saya selalu mendapatkan beasiswa untuk meningkatkan pendidikan" memiliki nilai ratarata yang paling rendah sebesar 6,64 sedangkan nilai variansnya sebaliknya yaitu memiliki yang paling besar yaitu 5,73. Pada nilai penilaian antara 1-6 dimana masuk pada kategori mereka yang kurang setuju akan apa yang mereka alami yaitu sebesar $15,28 \%$ karyawan yang merasakan hal tersebut.

\section{Hasil Analisis Verifikatif}

Sebagaimana telah dijelaskan pada bab sebelumnya bahwa penelitian ini bertujuan untuk mengetahui pengaruh rotasi dan kompetensi terhadap motivasi serta dampaknya pada kepuasan karyawan non Dosen Sekolah Teknik Elektro dan Informatika Institut Teknologi Bandung. Untuk keperluan analisis maka dilakukan analisis jalur. Perhitungan analisis jalur dalam penelitian ini. 


\section{Uji Normalitas Data}

Sebelum dilakukan analisis jalur (path analysis), terlebih dahulu dilakukan uji normalitas data untuk mengetahui apakah data yang digunakan memiliki distribusi normal atau tidak. Uji normalitas data yang dipakai dalam penelitian ini menggunakan metode kolmogorov smirnov dengan hasil sebagai berikut:

Tabel 1.10

Hasil Uji Normalitas Data

One-Sample Kolmogorov-Smirnov Test

\begin{tabular}{|c|c|c|}
\hline & & $\begin{array}{c}\text { Unstandardized } \\
\text { Residual }\end{array}$ \\
\hline \multirow{3}{*}{$\begin{array}{l}\text { N } \\
\text { Normal Parameters }{ }^{a, b}\end{array}$} & & 85 \\
\hline & Mean &, 0000000 \\
\hline & Std. Deviation & 10,61829803 \\
\hline \multirow[t]{3}{*}{ Most Extreme Differences } & Absolute &, 134 \\
\hline & Positive &, 113 \\
\hline & Negative &,- 134 \\
\hline Kolmogorov-Smimov $Z$ & & 1,238 \\
\hline Asymp. Sig. (2-tailed) & &, 093 \\
\hline
\end{tabular}

Sumber : Data primer yang diolah, 2014

Dari hasil pengujian normalitas data di atas terlihat bahwa nilai signifikansi pada residual sebesar 0,093 lebih besar dari 0,05 yang menunjukan bahwa nilai residual dalam data berdistribusi secara normal.

\section{Perhitungan Koefisien Analisis Jalur}

Dalam perhitungan pada koefisien analisis jalur, dalam penelitian ini penulis membagi proses perhitungan pada analisis jalur menjadi dua bagian yaitu perhitungan koefisien analisis jalur pada struktur.

\section{Perhitungan Koefisien Analisis Jalur Struktur}

Tahap pertama adalah mencari koefisien jalur untuk mencari pengaruh dari variabel bebas $(\mathrm{X})$ terhadap variabel terikat (Y). Dari hasil pengolahan data diperoleh matriks korelasi antara variabel bebas $(\mathrm{X})$ seperti dibawah ini:

$$
\mathbf{R}=\begin{gathered}
X_{1} \\
X_{2}
\end{gathered}\left[\begin{array}{cc}
X_{1} & X_{2} \\
1,000 & 0,593 \\
0,593 & 1,000
\end{array}\right]
$$


Nilai korelasi antar variabel bebas di atas kemudian dicari invers-nya, dan diperoleh hasil sebagai berikut:

$$
\mathbf{R}^{-1}=\begin{aligned}
& X_{1} \\
& X_{2}
\end{aligned}\left[\begin{array}{cc}
X_{1} & X_{2} \\
1,543 & -0,916 \\
-0,916 & 1,543
\end{array}\right]
$$

Selanjutnya, penulis melakukan perhitungan matriks korelasi antar variabel bebas $\mathrm{X}$ dengan Y:

$$
\mathbf{R}_{\mathbf{y x}}=\begin{aligned}
& X_{1} \\
& X_{2}
\end{aligned}\left[\begin{array}{c}
Y \\
0,586 \\
0,565
\end{array}\right]
$$

Untuk memperoleh koefisien jalur, maka matriks invers korelasi dikalikan dengan matriks korelasi antar variabel bebas $\mathrm{X}$ dengan variabel terikat $\mathrm{Y}$, sebagai berikut:

$$
\begin{aligned}
& \begin{array}{l}
\mathrm{PYX}_{1} \\
\mathrm{PYX}_{2}
\end{array}=\left[\begin{array}{cc}
1,543 & -0,916 \\
-0,916 & 1,543
\end{array}\right] \mathrm{X}\left[\begin{array}{l}
0,586 \\
0,565
\end{array}\right] \\
& \begin{array}{l}
\mathrm{PYX}_{1} \\
\mathrm{PYX}_{2}
\end{array}=\left[\begin{array}{l}
0,386 \\
0,336
\end{array}\right]
\end{aligned}
$$

Setelah koefisien jalur diperoleh, maka besar pengaruh gabungan dari kedua variabel bebas yang terdiri dari rotasi $\left(\mathrm{X}_{1}\right)$ dan kompetensi $\left(\mathrm{X}_{2}\right)$ terhadap motivasi (Y), dapat ditentukan dari hasil perkalian antara koeofisien jalur dengan matriks korelasi antara variabel bebas dengan variabel terikat sebagai berikut: 


$$
\begin{aligned}
\mathrm{R}_{\mathrm{Y}\left(\mathrm{X}_{1} \mathrm{X}_{2}\right)} & =\left[\begin{array}{ll}
0,386 & 0,336
\end{array}\right] \mathrm{X}\left[\begin{array}{l}
0,586 \\
0,565
\end{array}\right] \\
\mathrm{R}^{2}{\mathrm{Y}\left(\mathrm{X}_{1} \mathrm{X}_{2}\right)} & =41,6 \%
\end{aligned}
$$

Dari hasil perhitungan diperoleh informasi bahwa pengaruh gabungan dari kedua variabel bebas yang terdiri dari rotasi $\left(\mathrm{X}_{1}\right)$ dan kompetensi $\left(\mathrm{X}_{2}\right)$ terhadap motivasi (Y) kerja karyawan non dosen pada STEI ITB sebesar 41,6\%, sedangkan sisanya sebesar 58,4\% merupakan pengaruh dari variabel lain yang tidak diteliti. Jika digambarkan, nilai korelasi antara variabel bebas, koefisien jalur dan pengaruh variabel lain yang sudah diperoleh tersebut dapat disajikan sebagai berikut:

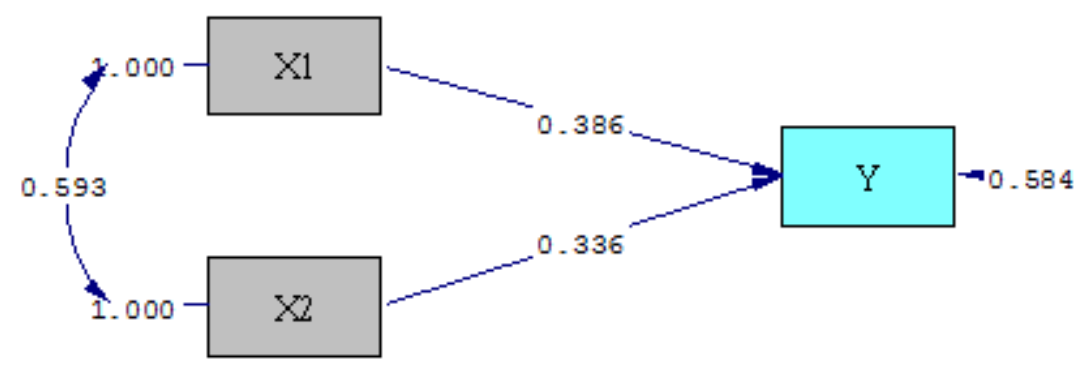

Gambar 1.2

Diagram Jalur Struktur

Dari gambar tersebut, hasil uji statistik memberikan jawaban atas penerapan analisis jalur pada sub struktur 1. Dilihat dari hasil korelasi antara Rotasi $\left(\mathrm{X}_{1}\right)$ dan Kompetensi $\left(\mathrm{X}_{2}\right)$ jika melihat hasil uji statistik didapat nilai korelasi sebesar 0,593 memiliki nilai cukup kuat yang merujuk pendapat Sugiyono, (2006 : 214). Selain itu juga dari hasil uji statistik mendapatkan pengaruh Rotasi $\left(\mathrm{X}_{1}\right)$ terhadap Motivasi (Y) memiliki nilai sebesar 0,386 dan selanjutnya nilai dari pengaruh Kompetensi $\left(\mathrm{X}_{2}\right)$ terhadap Motivasi (Y) sebesar 0,336. Pada epsilon dan atau keterkaitan hal lain yang tidak dilakukan pengujian sebesar 0,584 memiliki nilai yang cukup besar.

\section{Uji Kesesuaian Model Sub Struktur Pertama}

Uji kesesuaian model (goodnes of fit) maksudnya adalah menguji apakah model yang di usulkan memiliki kesesuaian (fit) dengan data atau tidak. Dalam kerangka Path Analyzsis, suatu model yang diusulkan dikatakan fit dengan data 
apabila matriks korelasi sampel tidak jauh berbeda dengan matrik korelasi estimasi (reproduced correlation matrix) atau korelasi yang diharapkan (expected correlation matrix). Karena itu, rumusan hipotesis statistik uji kesesuaian Path Analyzsis dirumuskan seperti berikut (Bachrudin \& Tobing dalam Kusnendi, 2005:37):

$\mathrm{H}_{0}: \mathrm{R}=\mathrm{R}(\boldsymbol{Q})$ : matrik korelasi sampel tidak berbeda dengan matriks korelasi estimasi.

$\mathrm{H}_{1}: \mathrm{R} \neq \mathrm{R}(\boldsymbol{Q})$ : matrik korelasi sampel berbeda dengan matriks korelasi estimasi.

$$
\begin{array}{r}
Q=\frac{1-R^{2} m}{1-M} \\
Q=\frac{1-0,416}{1-0,416} \\
Q=\frac{0,584}{0,584}=1
\end{array}
$$

Keterangan:

$\mathrm{R}^{2}=$ koefisien determinasi

$\mathrm{M}=\mathrm{R}_{\mathrm{m}}^{2}$ setelah dilakukan triming

Dari hasil perhitungan di atas terlihat bahwa hasil uji kesesuaian model dengan menggunakan uji Q adalah 1 karena dari hasil pengujian hipotesis kedua variabel bebas dinyatakan berpengaruh signifikan, sehingga setelah di uji kesesuaian model hasilnya adalah satu. Dengan demikian dapat dikatakan bahwa model fit sempurna, artinya dapat dikatakan bahwa matrik korelasi sampel tidak berbeda dengan matriks korelasi estimasi.

\section{Pengujian Hipotesis}

Pada tahapan pengujian hipotesis dalam penelitian ini, penulis mengkaji dan memproses data untuk selanjutnya dilakukan pengujian hipotesis baik secara simultan maupun parsial.

\section{Pengujian Hipotesis Secara Simultan (Uji F)}

Pada proses pengujian hipotesis secara simultan, penulis menggunakan uji statistiknya adalah sebagai berikut: 


$$
\begin{aligned}
& F=\frac{(n-k-1) \sum_{i=1}^{n} P_{Y i X i} r_{Y X i}}{k\left\{1-\sum_{i=1}^{n} P_{Y i X i} r_{Y X i}\right\}} \\
& F=\frac{(85-2-1) \times 0,416}{2\{1-0,416\}}=29,243
\end{aligned}
$$

Uji statistik di atas mengikuti distribusi F-snodecor dengan $\alpha=5 \%$ derajat kebebasan $\mathrm{db}_{1}=2$ dan $\mathrm{db}_{2}=85-2-1=82$, diperoleh F-tabel sebesar 3,108. Dari nilainilai tersebut terlihat bahwa nilai $\mathrm{F}_{\text {hitung }}$ yang diperoleh $(29,243)$ lebih besar dari nilai $\mathrm{F}_{\text {tabel }}(3,108)$.

Berdasarkan perhitungan diatas tersebut maka didapat:

\section{$H_{1}:$ tidak semua $\rho y x_{i} \neq 0 ; i=1,2$}

Artinya bahwa sekurang-kurangnya terdapat pengaruh dari rotasi $\left(\mathrm{X}_{1}\right)$ dan kompetensi $\left(\mathrm{X}_{2}\right)$ terhadap motivasi $(\mathrm{Y})$. Sehingga kriteria pengujian hiptesis bahwa $\mathrm{H}_{0}$ ditolak dan $\mathrm{H}_{1}$ diterima, artinya secara simultan kedua variabel bebas baik rotasi maupun kompetensi berpengaruh secara signifikan terhadap motivasi karyawan non dosen di STEI ITB.

\section{Uji Hipotesis Secara Parsial (Uji t)}

Selain itu juga untuk mengetahui nilai baik rotasi $\left(\mathrm{X}_{1}\right)$ dan kompetensi $\left(\mathrm{X}_{2}\right)$ maupun motivasi (Y) pada proses pengujian hipotesis secara parsial, dan untuk pengujian ini digunakan uji- $t$ maka pada perhitungan uji statistik dalam penelitian ini didapati dengan hasil sebagai berikut:

1) Uji Hipotesis Parsial $X_{1}$

Jika melihat rumus statistik dimana pada persamaan $\mathbf{H}_{\mathbf{1}}: \boldsymbol{\rho} \mathbf{y} \mathbf{x}_{\mathbf{1}} \neq \mathbf{0}$ artinya bahwa terdapat pengaruh rotasi $\left(\mathrm{X}_{1}\right)$ terhadap motivasi. Jika melihat hasil perhitungan dimana nilai t-hitung sebesar 3,686, berada diluar nilai t-tabel (1,989 dan 1,989). Maka, Secara parsial rotasi karyawan $\left(\mathrm{X}_{1}\right)$ berpengaruh signifikan terhadap motivasi kerja pegawai non Dosen STEI ITB.

2) Uji Hipotesis Parsial $X_{2}$ 
Selanjutnya penulis melakukan uji hipotesis bahwa kompetensi berpengaruh terhadap motivasi dimana dengan persamaan statistiknya yaitu $\mathbf{H}_{\mathbf{1}}: \boldsymbol{\rho} \mathbf{0} \mathbf{x}_{\mathbf{2}} \neq \mathbf{0}$ artinya bahwa terdapat pengaruh kompetensi $\left(\mathrm{X}_{2}\right)$ terhadap motivasi. Hasil parsial, kompetensi pegawai $\left(\mathrm{X}_{2}\right)$ berpengaruh signifikan terhadap motivasi kerja pegawai non Dosen STEI ITB, hal ini dapat ditunjukan dengan perolehan nilai t-hitung sebesar 3,206, berada diluar nilai t-tabel $(-1,989$ dan 1,989).

Tabel 1.11

Rekapitulasi Pengujian Hipotesis Parsial (Uji t)

\begin{tabular}{|c|c|c|c|}
\hline $\begin{array}{c}\text { Koefisien } \\
\text { Jalur }\end{array}$ & t-hitung & t-tabel & Kesimpulan \\
\hline $\mathrm{PYX}_{1}=0,386$ & 3,686 & $-1,989$ dan 1,989 & $\mathrm{H}_{0}$ Ditolak \\
\hline $\mathrm{PYX}_{2}=0,336$ & 3,206 & $-1,989$ dan 1,989 & $\mathrm{H}_{0}$ Ditolak \\
\hline
\end{tabular}

Sumber : Data primer yang diolah, 2014

Berdasarkan keterangan pada tabel di atas dapat penulis diinterpretasikan dari hasil penelitian ini bahwa dari hasil penelitian dimana nilai $\mathrm{t}_{\text {hitung }}$ lebih besar dari $\mathrm{t}_{\text {tabel }}$ $\left(0,386>0,201\right.$ dan 0,336 > 0,201) lebih besar maka dapat disimpulkan bahwa $\mathrm{H}_{0}$ dapat dinyatakan ditolak sedangkan pada hipotesis yaitu $\mathrm{H}_{1}$ diterima.

\section{Pengaruh Langsung dan Tidak Langsung Dari Rotasi dan Kompetensi Terhadap Motivasi Karyawan}

Berdasarkan hasil penelitian, diperoleh kesimpulan bahwa terdapat pengaruh yang signifikan dari kedua variabel yang terdiri dari rotasi dan kompetensi terhadap motivasi kerja pegawai pada STEI ITB. Untuk melihat lebih jauh tentang besar pengaruh langsung dan tidak langsung dari masing-masing variabel bebas terhadap variabel terikat, berikut disajikan rincian pengaruh langsung dan tidak langsungnya dapat dilihat seperti yang tertera pada tabel 4.17 sebagai berikut. 
Tabel 1.12

Besar Pengaruh Langsung dan Tidak Langsung

\begin{tabular}{|c|c|c|c|c|c|c|}
\hline \multirow{2}{*}{ Variabel } & $\begin{array}{c}\text { Koefisien } \\
\text { Jalur }\end{array}$ & $\begin{array}{c}\text { Pengaruh } \\
\text { Langsung } \\
(\%)\end{array}$ & $\begin{array}{c}\text { Pengaruh tidak } \\
\text { langsung } \\
\text { (melalui), dalam } \\
\%\end{array}$ & $\begin{array}{c}\text { Total } \\
\text { Pengaruh } \\
\text { Tidak } \\
\text { Langsung } \\
(\%)\end{array}$ & $\begin{array}{c}\text { Total } \\
\text { Pengaruh } \\
(\%)\end{array}$ \\
\cline { 4 - 5 } X1 & 0,386 & 14,93 & - & 7,704 & 7,7 & 22,6 \\
\hline X2 & 0,336 & 11,29 & 7,704 & - & 7,7 & 19,0 \\
\hline \multicolumn{7}{|c|}{ Total Pengaruh } \\
\hline
\end{tabular}

Sumber : Data primer yang diolah, 2014

Dari tabel besar pengaruh langsung maupun tidak langsung penulis menyimpulkan bahwa terdapat pengaruh langsung dan tidak langsung dari rotasi dan kompetensi terhadap motivasi. Dimana nilai pengaruh langsung dan tidak langsung dari variabel rotasi dan motivasi sebesar $22,6 \%$ dan $19,0 \%$.

a. Rotasi pegawai $\left(\mathrm{X}_{1}\right)$ memberikan pengaruh langsung terhadap motivasi kerja pegawai pada STEI ITB sebesar 14,93\% dan pengaruh tidak langsung melalui kompetensi $\left(\mathrm{X}_{2}\right)$ sebesar $7,7 \%$, sehingga total pengaruh rotasi pegawai terhadap motivasi pegawai sebesar $22,6 \%$.

b. Kompetensi $\left(\mathrm{X}_{2}\right)$ memberikan pengaruh langsung terhadap motivasi kerja pegawai pada STEI ITB sebesar 11,29\% dan pengaruh tidak langsung melalui rotas pegawai $\left(\mathrm{X}_{2}\right)$ sebesar $7,7 \%$, sehingga total pengaruh yang diberikan kompetensi pegawai terhadap motivasi kerja sebesar $19 \%$.

Dari kedua hal tersebut, penulis menyimpulkan bahwa baik rotasi maupun kompetensi sama-sama memiliki pengaruh baik secara langsung maupun tidak langsung.

\section{Analisis Perbandingan (Uji Beda)}

Analisis uji perbandingan atau uji beda dimana untuk melakukan uji perbandingan pada tiga kelompok data, perlu dilakukan uji asumsi terlebih dahulu yakni uji normalitas data dan uji homogenitas varians. Jika data berdistribusi normal dan memiliki varians yang homogen, dilakukan uji Anova. Jika data tidak berdistribusi normal maka dilakukan uji Kruskal Wallis (non parametrik), dan jika 
data berdistribusi normal namun varians tidak homogen maka digunakan uji-t independen.

\section{Uji Asumsi}

Dalam penelitian ini, guna mendukung hasil penelitian penulis melakukan uji asumsi. Dimana dalam proses uji asumsi melibatkan uji normalitas dan uji homogenitas sehingga dapat memberikan jawaban dan proses kelanjutan yang memadai dalam proses penelitian ini.

\section{Uji Normalitas Data}

Uji normalitas data menggunakan metode Kolmogorov Smirnov, dengan ketentuan jika $p$-value $>$ 0,05 maka data dinyatakan berdistribusi normal. Hasil uji normalitas disajikan sebagai berikut :

Tabel 1.13

Hasil Uji Normalitas Data Semua Variabel

\begin{tabular}{|c|c|c|c|c|c|c|}
\hline \multirow{2}{*}{ Variabel } & \multicolumn{6}{|c|}{ Kelompok } \\
\cline { 2 - 8 } & \multicolumn{2}{|c|}{ PNS } & \multicolumn{2}{c|}{ BHMN } & \multicolumn{2}{c|}{ Kontrak } \\
\cline { 2 - 8 } & Sig & Kesimpulan & Sig & Kesimpulan & Sig & Kesimpulan \\
\hline Rotasi & 0,144 & Normal & 0,888 & Normal & 0,833 & Normal \\
\hline Kompetensi & 0,195 & Normal & 0,098 & Normal & 0,971 & Normal \\
\hline Motivasi & 0,151 & Normal & 0,299 & Normal & 0,17 & Normal \\
\hline Kepuasan & 0,567 & Normal & 0,922 & Normal & 0,909 & Normal \\
\hline
\end{tabular}

Sumber : Data primer yang diolah, 2014

Dari data yang disajikan pada tabel di atas terlihat bahwa nilai signifikansi yang diperoleh ketiga kelompok tersebut lebih besar dari 0,05 yang menunjukan bahwa data untuk ketiga kelompok tersebut berdistribusi secara normal. Dengan demikian asumsi normalitas data dalam penelitian ini sudah terpenuhi.

\section{Uji Homogenitas Varians}

Hal ini dilakukan dalam rangka pengujian homogenitas varians untuk dapat mendukung proses analisis data pada proses selanjutnya. Metode Levine untuk proses pengujian homogenitas varians, dengan ketentuan proses pengujiannya yaitu 
jika jika p-value > 0,05 maka ketiga kelompok data dinyatakan memiliki varians yang homogen. Hasil uji homogenitas varians disajikan seperti berikut.

Tabel 1.14

Hasil Uji Homogenitas Varians

Test of Homogeneity of Variances

\begin{tabular}{|l|r|r|r|r|}
\hline & $\begin{array}{c}\text { Levene } \\
\text { Statistic }\end{array}$ & df1 & \multicolumn{1}{c|}{ df2 } & \multicolumn{1}{c|}{ Sig. } \\
\hline Rotasi & 4,880 & 2 & 82 &, 010 \\
Kompetensi & 1,266 & 2 & 82 &, 287 \\
Motivasi & 2,549 & 2 & 82 &, 084 \\
Kepuasan &, 908 & 2 & 82 &, 408 \\
\hline
\end{tabular}

Sumber : Data primer yang diolah, 2014

Tabel tersebut menunjukan hasil uji statistik yang melakukan proses pengujian pada tingkat homogenitas varians terhadap variabel yang digunakan dan diujikan dalam penelitian ini. Dari data yang disajikan pada tabel tersebut dapat terlihat bahwa nilai signifikansi yang diperoleh variabel kompetensi, motivasi dan kepuasan lebih dari 0,05 sehingga dinyatakan hasil analisis uji statistik pada penelitian ini mendapatkan data dari kompetensi dan motivasi maupun kepuasan dapat dikatakan sudah homogen. Kecuali untuk variabel rotasi memiliki nilai signifikansi kurang dari 0,05 sehingga dinyatakan tidak homogen.

\section{Analisis Perbandingan Rotasi Berdasarkan Status Pekerjaan}

Untuk tahap selanjutnya, penulis melakukan analisis perbandingan dimana hal ini menyesuaikan dengan hasil uji asumsi, analisis perbandingan kelompok rotasi berdasarkan jenis pekerjaan yaitu analisis rotasi pegawai menggunakan uji tindependen, yaitu penulis melakukan analisis perbandingan kelompok PNS dengan kontrak, kelompok PNS dengan BHMN, kelompok BHMN dengan kontrak. Berikut hasil dari analisis perbandingan tersebut seperti berikut.

Tabel 1.15

Perbandingan Rotasi Karyawan Berdasarkan Status Pekerjaan

\begin{tabular}{|c|c|c|c|c|}
\hline Perbandingan & Selisih rata-rata & t-hitung & t-tabel & p-value \\
\hline PNS vs BHMN & 0,440 & 1,531 & 2,000 & 0,131 \\
\hline PNS vs Kontrak & 1,095 & 2,504 & 2,013 & 0,018 \\
\hline BHMN vs Kontrak & 0,655 & 1,511 & 2,002 & 0,141 \\
\hline
\end{tabular}


Sumber : Data primer yang diolah, 2014

Dari hasil pengolahan data yang disajikan pada tabel di atas terlihat bahwa selisih rata-rata antara PNS vs BHMN sebesar 0,440. Dari hasil uji perbandingan menggunakan uji t-independen, diperoleh nilai signifikansi sebesar 0,131>0,05. Hal ini menunjukan bahwa rotasi pegawai yang berstatus sebagai PNS dengan pegawai BHMN tidak berbeda signifikan. Dari hasil uji perbandingan kedua antara PNS vs karyawan kontrak, diperoleh nilai selisih rata-rata sebesar 1,095. Hal ini menunjukan bahwa rotasi pegawai lebih sering terjadi pada pegawai yang berstatus PNS dari pada pegawai kontrak. Dari hasil pengujian hipotesis, diperoleh nilai signifikansi sebesar $0,018<0,05$ yang menunjukan bahwa rotasi pegawai pada PNS berbeda secara signifikan dengan pegawai kontrak. Serta dapat dilihat dari hasil pengujian terakhir antara pegawai BHMN dengan karyawan kontrak, diperoleh nilai selisih rata-rata sebesar 0,655 . Hal ini menunjukan bahwa rotasi pegawai BHMN lebih sering terjadi jika dibandingkan dengan pegawai yang berstatus kontrak. Tetapi dari hasil pengujian hipotesis diperoleh nilai signifikansi sebesar 0,141>0,05 yang menunjukan bahwa rotasi pada pegawai BHMN tidak berbeda signifikan dengan rotasi pada pegawai yang berstatus kontrak.

\section{Analisis Perbandingan Kompetensi Karyawan Berdasarkan Status Pekerjaan}

Untuk melakukan analisis perbandingan pada kompetensi pegawai berdasarkan status pekerjaan, penulis mengunakan uji perbandingan dengan menggunakan metode ANOVA. Adapun dari hasil uji perbandingan tersebut didapati dengan hasil dari pengolahan data statistik yang disajikan pada tabel 1.16 sebagai berikut:

Tabel 1.16

Perbandingan Kompetensi Pegawai Berdasarkan Status Pekerjaan

\begin{tabular}{|l|c|c|c|c|c|}
\hline $\begin{array}{l}\text { Sumber } \\
\text { Variasi }\end{array}$ & $\begin{array}{c}\text { Derajat } \\
\text { Kebebasan (DK) }\end{array}$ & $\begin{array}{c}\text { Jumlah } \\
\text { Kuadrat (JK) }\end{array}$ & $\begin{array}{c}\text { Kuadrat } \\
\text { Tengah }\end{array}$ & F & F tabel \\
\cline { 1 - 4 } Rata-rata & & 2,576 & 1,288 & \multirow{2}{*}{1,148} & 0,322 \\
\hline Perlakuan & 2 & 91,98 & 1,122 & \\
\hline Kekeliruan & 82 & & & \\
\hline
\end{tabular}


\begin{tabular}{l|l|l|l|} 
Total & 84 & 94,556 & \\
\hline
\end{tabular}

Sumber : Data primer yang diolah, 2014

Pada tabel 4.22 tersebut menunjukan perbandingan kompetensi karyawan berdasarkan status pekerjaan. Dari data di atas diperoleh informasi bahwa nilai signifikansi yang diperoleh dari hasil perbandingan kompetensi berdasarkan status pekerjaan sebesar 0,322 lebih besar dari 0,05. Hal ini menunjukan bahwa kompetensi pegawai tidak berbeda signifikan dengan status pekerjaan.

\section{Analisis Perbandingan Motivasi Karyawan Berdasarkan Status Pekerjaan}

Untuk tahap berikutnya, dilakukan uji perbandingan motivasi berdasarkan status pekerjaan. Pengujian ini dimaksud untuk mendapatkan hasil bagaimana perbandingan motivasi karyawan dari status pekerjaan yang mereka dapatkan selama ini. Hal ini juga untuk dapat dilakukan dengan menggunakan uji perbandingan dengan menggunakan ANOVA. Adapun hasil analisis mengenai hal tersebut dapat penulis gambarkan pada hasil seperti yang tertera pada tabel 1.17.

Tabel 1.17

Perbandingan Motivasi Pegawai Berdasarkan Status Pekerjaan

\begin{tabular}{|l|c|c|c|c|c|}
\hline $\begin{array}{l}\text { Sumber } \\
\text { Variasi }\end{array}$ & $\begin{array}{c}\text { Derajat } \\
\text { Kebebasan } \\
(\mathrm{DK})\end{array}$ & $\begin{array}{c}\text { Jumlah } \\
\text { Kuadrat } \\
(\mathrm{JK})\end{array}$ & $\begin{array}{c}\text { Kuadrat } \\
\text { Tengah }\end{array}$ & $\mathrm{F}$ & $\mathrm{F}_{\text {tabel }}$ \\
\hline Rata-rata & & & & \multirow{2}{*}{1,160} & 0,318 \\
\hline Perlakuan & 2 & 2,685 & 1,3425 & \\
\hline Kekeliruan & 82 & 94,88 & 1,157 & \\
\hline Total & 84 & 97,565 & & & \\
\hline
\end{tabular}

Tabel di atas menunjukan perbandingan motivasi pegawai berdasarkan status pekerjaan. Dari data di atas diperoleh informasi bahwa nilai signifikansi yang diperoleh dari hasil perbandingan motivasi berdasarkan status pekerjaan sebesar 0,318 lebih besar dari 0,05. Dikarenakan hasil analisis data tersebut dimana pada penelitian ini menunjukan bahwa motivasi pegawai tidak berbeda signifikan dengan status pekerjaan. 


\section{SIMPULAN}

Berdasarkan hasil analisis data dan pembahasan yang telah dilakukan, penulis mengambil beberapa kesimpulan untuk menjawab hipotesis mengenai analisis deskriptif yang meliputi rotasi, kompetensi, motivasi dan kepuasan, penulis menyimpulkan bahwa:

1. Kondisi rotasi secara umum dapat dinilai baik. Hal ini selaras dengan perolehan nilai indeks total sebesar 3759 dan didapat hasil nilai rata-rata sebesar 7,37. Namun dalam penelitian ini ditemukan masih adanya atau kecenderungan rotasi tidak memiliki hal yang positif guna menambah semangat dengan hasil nilai varians sebesar 4,91 dan nilai rata-rata sebesar 7,11 dimana nilai rata-rata yang terendah dan memiliki nilai varians paling tinggi. Selain itu ditemukan adanya responden yang masih kurang puas terhadap rotasi itu sendiri dengan nilai $17,00 \%$.

2. Kondisi kompetensi secara umum dapat dinilai baik, karena dari hasil perhitungan dengan nilai indeks keseluruhan mendapai 4108 dengan nilai ratarata sebesar 7,95. Hal ini selaras dengan nilai varian didapati nilai sebesar 3,39 paling tinggi dan nilai rata-rata yang paling rendah. Selain itu dalam penelitian ini juga ditemukan responden sebesar 8,76\% masih kurang memiliki kompetensi yang sesuai harapan mereka.

3. Kondisi motivasi juga secara keseluruhan dengan nilai total 3834 dan diperoleh nilai rata-rata terhadap variabel motivasi sebesar 7,64 dapat dikategorikan merupakan hal yang baik. Motivasi karyawan masih perlu ditingkatkan peluang mendapatkan beasiswa untuk meningkatkan jenjang pendidikannya sebesar 6,64. Selain itu dari nilai varians pada variabel motivasi ini ditemukan adanya kecenderungan dari proses motivasi untuk dapat ditingkatkan dengan nilai varian tertinggi sebesar 5,73 dengan nilai rata-rata paling rendah sebesar 6,64.

Pada proses pembahasan selanjutnya yaitu pada bagian kedua ini penulis menyimpulkan dari hasil analisis secara verifikatif dimana dari hasil penelitian pada uji hipotesis secara simultan maupun parsial:

1. Secara simultan, rotasi pegawai dan kompetensi memberikan pengaruh yang signifikan terhadap motivasi kerja karyawan STEI ITB dengan kontribusi yang 
diberikan sebesar 41,6\%, sedangkan sisanya sebesar 58,4\% merupakan pengaruh dari faktor lain yang tidak diteliti. Hal ini juga didukung dari perolehan $\mathrm{F}_{\text {tabel }}$ sebesar 3,108 sementara perolehan $\mathrm{F}_{\text {hitung }}$ sebesar 29,343 dengan demikian dapat disimpulkan bahwa secara simultan kedua variabel bebas yang terdiri dari rotasi, kompetensi berpengaruh secara signifikan terhadap motivasi karyawan non Dosen STEI ITB.

2. Secara parsial dalam penelitian ini penulis menyimpulkan bahwa:

a. rotasi karyawan memberikan pengaruh yang signifikan terhadap motivasi kerja karyawan STEI ITB dengan kontribusi yang diberikan sebesar 22,6\%. Selain itu hal ini didukung dengan ditunjukan perolehan nilai t-hitung sebesar 3,686, berada diluar nilai t-tabel (-1,989 dan 1,989).

b. Lebih lanjut yaitu pada pengujian secara parsial untuk kompetensi juga memberikan pengaruh yang signifikan terhadap motivasi kerja karyawan STEI ITB dengan kontribusi yang diberikan sebesar 19\%. Selain itu hal ini didukung dengan ditunjukan perolehan nilai t-hitung sebesar 3,206, berada diluar nilai t-tabel (-1,989 dan 1,989).

3. Pengaruh langsung dan tidak langsung baik rotasi maupun kompetensi terhadap motivasi dalam penelitian ini memiliki nilai total sebesar 41,6\%. Dimana pengaruh langsung dan tidak langsung dari variabel rotasi terhadap motivasi sebesar 22,6\% dan pengaruh langsung dan tidak langsung variabel kompetensi terhadap motivasi sebesar 19,0\%. Dimana pengaruh langsung rotasi terhadap motivasi sebesar 14,93\% sedangkan pengaruh tidak langsungnya sebesar 7,7\%. Sedangkan pengaruh langsung kompetensi terhadap motivasi sebesar 11,29\% dan pengaruh tidak langsung sebesar $7,7 \%$.

\section{DAFTAR PUSTAKA}

Arikunto, Suharsimi, (2006). Prosedur Penelitian Suatu Pendekatan Praktik. Jakarta : PT. Rineka Cipta.

Arwildayanto, (2013). Manajemen Sumber Daya Manusia Perguruan Tinggi : Pendekatan Budaya Kerja Dosen Profesional. Bandung : Alfabeta.

Bramming, Pia, (2000). Competence is competence. Copenhagen Business School.

David, Fred R, (2011). Manajemen Strategi Konsep. Jakarta : Salemba Empat.

Dhermawan, Anak Agung Ngurah Bagus, Sudibya, I Gde Adnyana dan Utama, I Wayan Mudiartha, (2012). Pengaruh Motivasi, Lingkungan Kerja, 
Kompetensi dan Kompensasi Terhadap Kepuasan Kerja dan Kinerja Pegawai di Lingkungan Kantor Dinas Pekerjaan Umum Provinsi Bali. Universitas Udayana-Jurnal Manajemen, Strategi Bisnis dan Kewirausahaan, Vo. 6, No.2.

Fitriani, Diah dan Daromi, Sunardji, (2005). Analisis Hubungan Antara Kepuasan Karyawan dan Kepuasan Pelanggan dengan Mediasi Kualitas Pelayanan. Hal. 41-58, Sinergi - Kajian Bisnis dan Manajemen.

Gijoh, Rienly, (2013). Motivasi, Kompetensi dan Budaya Kerja Pengaruhnya Terhadap Kepuasan Kerja Karyawan Outsourcing pada Hotel Sintesa Peninsula Manado. Jurnal EMBA, Vol.1 No.4.

Kotler, Philip \& Keller, Kevin Lane,(2011) Manajemen Pemasaran : Edisi Ketiga Belas. Northwestern University \& Dartmounth College.

Mangkunegara, Anwar Prabu. (2004). Manajemen Sumber Daya Manusia Perusahaan. Bandung: PT Remaja Rosdakarya.

Mitrani, A, Daziel, M. dan Fitt, D, (1992). Competence based Human Resource Management: Value-Driven Strategies for Recuitment, Development and Reward. London: Kogan Page Limited.

Nasution, (2008). Metode Reseach : (Penelitian Ilmiah). Jakarta : PT. Bumi Aksara.

Nickels, William G., McHugh, James M., McHugh, Susan M, (2009). Pengantar Bisnis : Edisi Kedelapan. Jakarta : Salemba Empat.

Noe, Raymond A., Hollenbeck, John N. et.al. (2011). Manajemen Sumber Daya Manusia, Mencapai Keunggulan Bersaing. Jakarta : Salemba Empat.

Palan, R. (2007). Comptency Manajement. Teknik Mengimplementasikan Manajemen SDM Berbasis Kompetensi untuk Meningkatkan Daya Saing Organisasi. Penerjemah: Octa Melia Jalal. PPM: Jakarta.

Sandjojo, Nidjo, (2011). Metode Analisis Jalur (Path Analysis) dan Aplikasinya. Jakarta : Pustaka Sinar Harapan.

Sekaran, Uma, (2006), Research Methods for Business. Jakarta : Salemba Empat

Spencer, M. Lyle dan Spencer, M. Signe, (1993). Competence at work: Models for Superior Performance. New York, John Wily \& Son.Inc.

Sugiyono, (2006). Metodologi Penelitian Kualitatif dan Kuantitatif. Bandung : Alfa Beta.

Sule, Ernie Trisnawati \& Saefullah, Kurniawan, (2010). Pengantar Manajemen: Edisi Pertama. Jakarta: Kencana.

Sumarsono, Sonny, (2003). Ekonomi Manajemen Sumber Daya Manusia dan Ketenagakerjaan. Yogyakarta : Graha Ilmu.

Supranto, (2000). Statistik : Teori dan Aplikasi - Edisi Keenam. Jakarta : Erlangga.

Wexley, Kenneth N. dan Yuki, Gary A. (2005). Perilaku Organisasi dan Psikologi Personalia. Terjemahan Shobaruddin Muh. Jakarta: PT Asdi Mahasatya. 